\title{
Truncating de novo mutations in the Krüppel-type zinc-finger gene ZNF148 in patients with corpus callosum defects, developmental delay, short stature, and dysmorphisms
}

\author{
Servi J. C. Stevens ${ }^{1 * \dagger}$, Anthonie J. van Essen ${ }^{2+}$, Conny M. A. van Ravenswaaij ${ }^{2}$, Abdallah F. Elias ${ }^{3}$, Jaclyn A. Haven ${ }^{3}$, \\ Stefan H. Lelieveld ${ }^{4}$, Rolph Pfundt ${ }^{4}$, Willy M. Nillesen ${ }^{4}$, Helger G. Yntema ${ }^{4}$, Kees van Roozendaal ${ }^{1,4}$, \\ Alexander P. Stegmann ${ }^{1}$, Christian Gilissen ${ }^{4}$ and Han G. Brunner ${ }^{1,4}$
}

\begin{abstract}
Background: Krüppel-type zinc finger genes (ZNF) constitute a large yet relatively poorly characterized gene family. ZNF genes encode proteins that recognize specific DNA motifs in gene promotors. They act as transcriptional co-activators or -repressors via interaction with chromatin remodeling proteins and other transcription factors. Only few ZNF genes are currently linked to human disorders and identification of ZNF gene-associated human diseases may help understand their function. Here we provide genetic, statistical, and clinical evidence to support association of ZNF148 with a new intellectual disability (ID) syndrome disorder.

Methods: Routine diagnostic exome sequencing data were obtained from 2172 patients with ID and/or multiple congenital anomalies.

Results: In a cohort of 2172 patient-parent trios referred for routine diagnostic whole exome sequencing for ID and/or multiple congenital anomalies (MCA) in the period 2012-2016, four patients were identified who carried de novo heterozygous nonsense or frameshift mutations in the ZNF148 gene. This was the only ZNF gene with recurrent truncating de novo mutations in this cohort. All mutations resulted in premature termination codons in the last exon of ZNF148. The number of the de novo truncating mutations in the ZNF148 gene was significantly enriched ( $p=5$. $42 \times 10^{-3}$ ). The newly described ZNF148-associated syndrome is characterized by underdevelopment of the corpus callosum, mild to moderate developmental delay and ID, variable microcephaly or mild macrocephaly, short stature, feeding problems, facial dysmorphisms, and cardiac and renal malformations.

Conclusions: We propose ZNF148 as a gene involved in a newly described ID syndrome with a recurrent phenotype and postulate that the ZNF148 is a hitherto unrecognized but crucial transcription factor in the development of the corpus callosum. Our study illustrates the advantage of whole exome sequencing in a large cohort using a parent-offspring trio approach for identifying novel genes involved in rare human diseases.
\end{abstract}

Keywords: ZNF148, ZBP-89, Whole exome sequencing, Intellectual disability, Corpus callosum development, De novo mutations, Premature termination codon

\footnotetext{
* Correspondence: servi.stevens@mumc.nl

${ }^{\dagger}$ Equal contributors

'Department of Clinical Genetics, Maastricht University Medical Center

(MUMC+), PO Box 58006202, AZ, Maastricht, The Netherlands

Full list of author information is available at the end of the article
} 


\section{Background}

The human genome contains over 400 Krüppel-type zinc finger (ZNF) genes. For many of these genes a biological function has not been elucidated thus far [1]. ZNF genes encode DNA-binding proteins, related to the archetypal Drosophila regulatory protein Krüppel, which recognizes specific DNA sequence motifs in gene promoters. They bind the major groove of the double helix by their $\mathrm{C} 2 \mathrm{H} 2$ zinc finger domains, each consisting of a chain of two cysteines and two histidines that fold around and are stabilized by a single $\mathrm{Zn}^{2+}$ ion. ZNF genes may function as either transcriptional coactivators or repressors. They do so by promoting the binding of transcription factors to their cognate DNA recognition site or by recruitment of chromatin remodeling proteins such as histone deacetylases, methyltransferases, and demethylases [1, 2]. Most ZNF genes have been characterized using in vitro binding and reporter assays for identification of their target genes. By identifying ZNF genes involved in human disease, their broader role in ontogeny or physiological processes may be elucidated. Despite the extensive size of the gene family, the number of disease-linked ZNF genes remains relatively small. Here we identified truncating de novo mutations in the Zinc Finger Protein 148 (ZNF148; also known as ZBP-89 or ZFP148) from a large cohort of patient-parents trios referred for diagnostic exome sequencing in the period 2012-2016. These de novo mutations lead to syndromic intellectual disability (ID) with corpus callosum anomalies and short stature as shared features, accompanied by secondary variable microcephaly or mild macrocephaly, feeding problems, variable facial features, talipes, and malformations of the heart and kidneys.

\section{Methods}

\section{Whole exome sequencing}

For whole exome sequencing (WES), a parent-offspring trio approach was used as described by us previously [3, 4]. Exomes were sequenced using DNA isolated from blood according to standard procedures. Exome capture was done using the Agilent SureSelect v4 kit (Agilent, Santa Clara, CA, USA). Exome libraries were sequenced on an Illumina HiSeq instrument (Illumina, San Diego, CA, USA) with 101 bp pairedend reads at a median coverage of $75 x$. Sequence reads were aligned to the hg19 reference genome using BWA version 0.5.9-r16. Variants were subsequently called by the GATK unified genotyper, version 3.2-2 and annotated using a custom diagnostic annotation pipeline. De novo variants in index patients were called as described by de Ligt et al. [4]. Standard Sanger sequencing of patient and parental DNA was used for validation de novo variants identified in WES data.

\section{Statistical analyses}

To assess whether de novo nonsense mutations in the ZNF148 gene occurred significantly more frequently in our ID/MCA patient cohort, we made use of the ZNF148specific loss-of-function (LoF) mutation rates [5], exactly as we described previously in Lelieveld et al. [6]. The LoF rate was calculated by summing the individual ZNF148 specific de novo mutation rates for nonsense, splice site, and frame-shift variants. Null hypothesis testing of finding three nonsense or splice site mutations in the ZNF148 gene was done using a one-sided exact Poisson test based on a sample size of 2172 individuals with ID/MCA, representing 4344 alleles. Bonferroni correction for multiple gene testing was applied by multiplying the obtained $p$ value by 19,280 , i.e. the number of genes captured by the exome capture kit. To statistically assess whether de novo mutations clustered within the ZNF148 gene, random distribution of the mutations over the entire coding region of the gene (2382 bp) was simulated 10,000 times [6]. The mutual distance between these randomly applied mutations was calculated and statistically compared to the actual distances between the observed de novo mutations in our patients, which were present at c. positions 970, 1581, 1582, and 1792 .

\section{Results \\ Clinical reports}

Patient 1 is a 6 -year-old girl born at $35+4$ weeks after an uncomplicated pregnancy who presented with respiratory insufficiency and severe feeding problems requiring gavage feeding. Birth measurements were normal. Currently, she has gastrointestinal dysmotility with delayed gastric passage and receives most of her caloric intake through a gastrostomy tube. Biochemical analysis of mitochondrial enzymes showed no abnormalities. Developmental milestones were reached late with independent walking and first words spoken at the age of 3 years. Her first teeth erupted after 3 years. She is hyperactive at times and she gets upset in crowded environments. WISCIII-III-NL (2.6-7.11 years) intelligence test at 5.6 years showed a total intelligence quotient (IQ) of 59 (95\% confidence interval (CI) 54-71), verbal IQ of 72 (68-85), and performance IQ score of 63 (57-77) indicating a mild intellectual delay. She attends a school for children with ID. Cardiac ultrasound for evaluation of a systolic murmur revealed a structurally normal heart. Physical examination at 6 years revealed the following. Her speech was difficult to understand because of poor pronunciation. She currently has mild developmental delay, hyperopia (+6.5 dioptres), secondary mild microcephaly $(-2.76 \mathrm{SD})$ and short stature (-2.29 SD), upslanted eyes, notched nares with visible columella, grooved philtrum, slightly prominent lower lip, pointed chin, and hypertrichosis of the arms and back. Cardiac ultrasound for evaluation of a systolic murmur 
revealed a structurally normal heart. Complaints of exertional chest pain remain unexplained. Magnetic resonance imaging (MRI) of her brain showed a thin hypoplastic corpus callosum.

Patient 2 was the first child of healthy unrelated parents. Prenatal ultrasound showed multiple congenital anomalies: agenesis of the corpus callosum, right hydronephrosis, left multicystic kidney, and bilateral pes equinovarus. Birth was by Caesarian section after $31+2$ weeks gestation because of fetal bradycardia. Apgar scores were 2-4-7 after 1, 3 , and $5 \mathrm{~min}$. After delivery, he was apneic, pale, hypotonic, and bradycardic with a heart rate of $60 / \mathrm{min}$. Renal ultrasound showed multicystic dysplastic right kidney and left hydronephrosis. Cardiac ultrasound showed open ductus arteriosus. Physical exam after birth and postmortem exam revealed short stature $(-2.5 \mathrm{SD})$ and a number of dysmorphic features including a small fontanel, flat occiput, coarse square shaped face, broad nasal bridge, wideset eyes with infraorbital creases, retrognathia, upturned nose, prominent columella, long smooth prominent philtrum, narrow palate, retrognathia with small chin, widespaced inverted nipples, $3 \mathrm{~cm}$ palpable liver, sacral dimple, flat buttocks, small male genitalia with inguinal testes, small hands and feet with dorsal furrowing of the skin, right helical notch, bilateral prominent crus helici, vertical groove in the left ear lobe, short neck, superfluous skin with hypertrichosis on face, uppers arms, legs, and back, and talipes equinovarus with deeply grooved skin of foot soles. Infant Respiratory Distress Syndrome (IRDS) developed with poor circulation and lactic acidosis persisting until death 6 days after birth. Postmortem investigation including brain MRI confirmed the renal abnormalities and corpus callosum agenesis as well as wide intracerebral ventricles in an otherwise normal brain.

Patient 3 is an 11-year-old girl, the second child of healthy Caucasian parents, born at $38+5$ weeks. Prenatal ultrasound at 32 weeks of gestation showed symmetric cerebral ventriculomegaly especially of the posterior horns. At birth, she was hypotonic and hyporeactive with respiratory insufficiency with Apgar scores of 5-6-8 at 1, 5, and $10 \mathrm{~min}$. Because of feeding problems, gavage was needed during the first 5 days. A capillary malformation on her forehead, nose, and upper lip faded in due time. She took her first independent steps at 2 years and said her first words at the age of 3 years. Axial hypotonia remained evident throughout childhood. Fast head growth in her first year led to secondary macrocephaly at 2 years, while short stature developed at 2 years in the presence of growth hormone deficiency for which growth hormone therapy was started at 3 years. She is hyperactive, shows compulsive behaviors, has frequent temper tantrums, and was diagnosed with PDD-NOS. WISCIII intelligence test at the age of 8 years showed a total IQ of 58, verbal IQ of 62, and performance IQ score of 69. Due to early breast development at the age of 8 years, Lucrin was given to prevent further development of puberty. Periodic palpitations and tachycardia at the age of 7 years remain unexplained after cardiologic examination including ECG and cardiac ultrasound. Physical examination at 7.2 years showed long face, high slightly prominent forehead, prominent occiput, mild macrocephaly (around $+2.5 \mathrm{SD}$ ), curly hair, trident hairline, down slanting palpebral fissures, minimal epicanthic folds, slightly hooded eyelids, prominent columella, malocclusion of upper and lower incisors, pointed chin, genua valga, and pedes plani. MRI scan of the brain revealed corpus callosum agenesis. The phenotype was considered suggestive of Noonan syndrome. However, no mutation was found after screening of all known genes linked with Noonan, CardioFacio-Cutaneous (CFC), and Costello syndromes.

Patient 4 is a 7 -year-old girl, the third child of a 30 -yearold mother and a 37-year-old father. Abnormal prenatal ultrasound findings, including cystic kidneys and a cardiac defect in the fetus, prompted amniocentesis which showed a normal female karyotype and normal FISH for 22q11 deletion. After delivery at 36 weeks after induction, she was apneic at birth responding to positive pressure ventilation (PPV); APGAR scores 4-7-8 at 1, 5, and $10 \mathrm{~min}$. Birth measurements were normal and bilateral clubfeet were noted. Coarctation of the aorta associated with mitral valve stenosis, overall consistent with hypoplastic left heart syndrome spectrum, were found on postnatal echocardiogram and initially managed with prostaglandin E1, followed by balloon dilation and aortic repair. Renal ultrasound showed a right-sided multicystic kidney. She developed feeding problems requiring tube feedings and growth restriction with normal growth hormone status and bone age. Her development has been globally delayed from early on and at the age of 6 years she had an expressive language disorder with very restricted vocabulary compared to relatively good receptive language skills. She is able to use sign language and assistive communication devices; she receives special education through the public health system. Her behavior is generally mellow, but she has social anxiety and becomes easily overstimulated. Ophthalmology and orthopedics are following her for hyperopia with mild bilateral optic nerve hypoplasia and bilateral clubfeet, respectively. She underwent repeated tympanostomy and bilateral tube placement for recurrent otitis media associated with conductive hearing loss. Physical features at the age of 7 years include severe microcephaly $(-8.7 \mathrm{SD})$ and short stature $(-5.11 \mathrm{SD})$ and bilateral clubfeet. Her distinct craniofacial gestalt is characterized by an oval-shaped head and face with mild bitemporal constriction, deep-set eyes with upslanting, short and narrow palpebral fissures, mild telecanthus, a prominent nose with low-hanging prominent columella, midface hypoplasia, prognathia, thin lips, highly arched palate, widely spaced teeth of abnormal shape, unusual 
ears with underfolded helices, prominent anthelix, and underdeveloped attached earlobes. Her neurological exam is non-focal. A computed tomography (CT) scan of the head was suggestive of partial dysgenesis of the corpus callosum. MRI of her brain was not performed.

Clinical features of the four patients with ZNF148 mutations are summarized in Table 1 . Clinical photographs are shown in Fig. 1.

\section{Genomic analyses}

During routine diagnostic WES in the Radboud University Medical Center (RUMC) in Nijmegen during the period 2012-2015 we identified patients 1-3, out of a total of 2172 WES trio analyses of patients with ID and/or MCA and both their parents. The three patients had heterozygous truncating de novo mutations in ZNF148, the only ZNF gene in which such mutations occurred recurrently in our cohort. Patient 4 was identified via GeneMatcher [7]. All four mutations were located in the last exon (exon 9) of the ZNF148 gene (reference sequence NM_021964.2) and were as follows: patient 1: c.1792A > T (p.Lys598*); patient 2: c.1583dup (p.Ser529Gluf**2); patient 3: c.970dup (p.Ser324Phefs"14); and patient 4: c.1581_182insC (p.Lys528Glnfs*3). These four de novo mutations all yield a premature termination codon (PTC) in the ZNF148 transcript, respectively, 458, 265, 197, and 265 codons upstream of the canonical wild-type termination codon (Fig. 2). Variants in additional genes were detected in three patients. Patient 1 had heterozygous de novo missense mutations of unknown significance in the TCERG1 gene (NM_006706.3:c.2359G > A; p.Asp787Asn) and in the SART3 gene (NM_014706.3:c.1526A > G; p.Asn509Ser), neither of which can be related to the clinical phenotype currently. Mutations in these two genes have not been described thus far and we did not observe other patients in our cohort harboring de novo mutations in these genes. Patient 3 showed a likely benign, homozygous missense variant in the PDCD4 gene (NM_014456.4:c.1198C > G; p.Gln400Glu), which has low heterozygous frequency in ExAC of $0.02 \%$ in Europeans [8] and which is also reported homozygously once in this database. In patient 4 , a maternally inherited heterozygous missense variant in COL3A1 (NM_000090.3 c.3938A > G; p.Lys1313Arg), was found. This variant has been classified as variant of uncertain significance (VUS) in ClinVar as variant RCV000181114.1 [9]. However, neither the patient nor his mother or other individuals on the maternal side of the family have clinical symptoms suggestive of vascular Ehlers-Danlos syndrome (EDS type IV), the only syndrome known to be caused by pathogenic mutations in COL3A1. Moreover, this COL3A1 variant has a MAF of $0.26 \%$ in Europeans in the Exome Variant Server [10].

Next, we calculated the statistical probability of the number of de novo nonsense and frameshift mutations in our entire cohort of 2172 WES parent-offspring trios sequenced at RUMC. There was a significant increased number of such mutations in the ZNF148 gene in our ID/MCA cohort $\left(p=5.42 \times 10^{-3}\right)$. The distribution of the four mutations was not random over the coding region of the ZNF148 gene, but the mutations were significantly clustered $(p=0.033)$.

\section{Discussion}

We detected de novo mutations in the last exon of ZNF148 in four patients and show significant enrichment of such mutations in our cohort of 2172 parent-offspring trios analyzed by WES. The core features in these four individuals with ZNF148-associated syndrome are: underdevelopment of the corpus callosum; mild to moderate developmental delay and ID; variable microcephaly or mild macrocephaly; short stature; feeding problems; facial dysmorphisms including wide-set eyes; low columella and pointed chin; and cardiac and renal malformations. But there were also noticeable differences between these four individuals. The clinical course in patient 1 is noteworthy for persisting feeding problems necessitating feeding by gastrostomy until now. Patient 2 had a coarse appearance and died from cardiac and pulmonary insufficiency on day 6 . Patient 3 had mild secondary macrocephaly and developed secondary growth retardation with growth hormone deficiency and showed catch-up growth to normal height with GH replacement therapy. The phenotype of patient 3 was very suggestive of Noonan syndrome but testing showed no mutation in all genes associated with Noonan, CFC, and Costello syndrome. Patient 4 has very short stature and had severe microcephaly from birth. Her facial features were reminiscent of Floating Harbor syndrome (FHS).

The absence of mutations leading to PTCs in the ZNF148 gene in the general population, their significant overrepresentation in our cohort, and ZNF148 constraint metrics, i.e. "Probability of Loss-of-function Intolerance" $(\mathrm{pLI})=0.93$ as described [8] and absence of nonsense or frameshift mutations in $>100,000$ alleles in ExAC [8] and a high rank haploinsuffiency (HI) score of 10.07 [11], strongly indicate that this gene is highly intolerant to truncating mutations. These calculations in combination with the phenotypical overlap in the identified patients strongly support causality for the de novo PTC mutations in ZNF148.

ZNF148 encodes a Krüppel-type zinc finger protein, with four $\mathrm{C} 2 \mathrm{H} 2$ zinc finger motifs that bind similar DNA sequence elements in different gene promoters [12]. A BLASTP search [13] showed no apparent homology to other ZNF genes and the gene is relatively poorly characterized with regard to tissue-specific expression. However, ZNF148 mRNA is ubiquitously transcribed throughout numerous anatomical structures of the developing human fetal brain with highest expression in most regions until 16 weeks post conception [14, 15]. Unfortunately, no data are available on the gene's expression in the developing 
Table 1 Clinical features of four patients with de novo mutations in the last exon of the ZNF148 gene

\begin{tabular}{|c|c|c|c|c|}
\hline & Patient 1 & Patient 2 & Patient 3 & Patient 4 \\
\hline $\begin{array}{l}\text { Gender and } \\
\text { current age }\end{array}$ & Girl, 6.7 years & $\begin{array}{l}\text { Boy, died on postnatal } \\
\text { day } 6 \text { after sudden } \\
\text { bradycardia }\end{array}$ & Girl, 11.7 years & Girl, 7 years \\
\hline $\begin{array}{l}\text { ZNF148 } \\
\text { mutation }\end{array}$ & c.1792A > T; p.Lys598* & $\begin{array}{l}\text { c.1583dup; } \\
\text { p.Ser529Glufs*2 }\end{array}$ & c.970dup; p.Ser324Phefs*14 & c.1581_1582insC; p.Lys528Glnfs*3 \\
\hline $\begin{array}{l}\text { Additional } \\
\text { variants }\end{array}$ & $\begin{array}{l}\text { SART3 c.1526A > G; p.Asn509Ser } \\
\text { TCERG1 c.2359G > A; p.Asp787Asn }\end{array}$ & None & $\begin{array}{l}\text { PDCD4 c.1198C > G; p.Gln400Glu } \\
\text { homozygous }\end{array}$ & $\begin{array}{l}\text { COL3A1 c.3938A > G; p.K1313R; } \\
\text { heterozygous, maternally inherited, } \\
\text { MAF 0.26\%; classified as VUS in } \\
\text { ClinVar (RCV000181114.1) }\end{array}$ \\
\hline Pregnancy & $\begin{array}{l}\text { Uncomplicated, mother noted } \\
\text { diminished fetal movements }\end{array}$ & $\begin{array}{l}\text { Decelerative CTG just } \\
\text { before birth }\end{array}$ & Uncomplicated & $\begin{array}{l}\text { Renal cysts and heart defect on } \\
\text { fetal ultrasound }\end{array}$ \\
\hline Birth & Uneventful, 35 + 4 weeks & $\begin{array}{l}\text { CS at } 31+2 \text { weeks, } \\
\text { Apgar scores 2-4-7, not } \\
\text { breathing, pale, hypo- } \\
\text { tonic, and lactic acid- } \\
\text { osis postpartum }\end{array}$ & $\begin{array}{l}\text { CS at } 38+5 \text { weeks, Apgar scores } \\
5-6-8 \text {, hypotonic and hyporeac- } \\
\text { tive, Continuous Positive Airway } \\
\text { Pressure for respiratory } \\
\text { insufficiency }\end{array}$ & $\begin{array}{l}\text { Induced vaginal delivery at } 36+ \\
0 \text { weeks. Apgar scores } 4-7-8 \text {. Ap- } \\
\text { neic at delivery, responding to } \\
\text { PPV. Started on PGE for known } \\
\text { COA. }\end{array}$ \\
\hline Birth weight & 2.68 kg (-0.30 SD) & 1.84 kg (+0.04 SD) & 3.315 kg (+0.14 SD) & 1.990 kg (-1.49 SD) \\
\hline Birth length & $47 \mathrm{~cm}(-0.37 \mathrm{SD})$ & $39 \mathrm{~cm}(-2.62$ SD) & $49 \mathrm{~cm}(-0.50 \mathrm{SD})$ & $42 \mathrm{~cm}(-2.55 \mathrm{SD})$ \\
\hline Birth head & $32 \mathrm{~cm}(-0.75 \mathrm{SD})$ & $29.2 \mathrm{~cm}(-0.37 \mathrm{SD})$ & $35 \mathrm{~cm}(+0.49 \mathrm{SD})$ & $28.5 \mathrm{~cm}(-3.2 \mathrm{SD})$ \\
\hline
\end{tabular}

$\begin{array}{lll}\begin{array}{l}\text { Feeding } \\ \text { problems }\end{array} & \begin{array}{l}\text { Severe, tube feeding need for } \\ \text { sufficient caloric intake }\end{array} & \text { Not applicable } \\ \text { Length } & 110.2(-2.29 \text { SD) at } 6.6 \text { years } & \begin{array}{l}40 \mathrm{~cm}(-2.5 \mathrm{SD}) \\ \text { at } 6 \text { days }\end{array}\end{array}$

$\begin{array}{lll}\text { Weight } & \begin{array}{l}17 \mathrm{~kg}(-1.09 \mathrm{SD} \text { for length) at } \\ 6.6 \text { years }\end{array} & \begin{array}{l}1.84 \mathrm{~kg}(+0.04 \mathrm{SD}) \\ \text { at } 6 \text { days }\end{array} \\ \begin{array}{ll}\text { Head } \\ \text { circumference }\end{array} & (-2.76 \mathrm{SD}) \text { at } 6.5 \text { years } & \begin{array}{l}29.2 \mathrm{~cm}(-0.37 \mathrm{SD}) \\ \text { at } 6 \text { days }\end{array}\end{array}$

Feeding problems during first week with 5 days of tube feeding

$151.7(+0.04 \mathrm{SD})$ at 11.3 years, catch up with growth hormone substitution therapy started at 3 years because of growth retardation (-2.48 at 2.7 years), and growth hormone deficiency

$38.4 \mathrm{~kg}$ (-0.33 SD for length) at 11.3 years

$58.2 \mathrm{~cm}(+2.84 \mathrm{SD})$ at 11.3 years and fluctuating above and below +3 SD between 6 and 10 years

Walked independently at 4 years and started talking $>3$ years

Developmental Walked independently at 3 years. Not applicable milestones Spoke 3 years

$\begin{array}{ll}\text { Cognition } & \text { WPPS1-III (2.6-3.1 years) at } \\ & 3.7 \text { years: TIQ } 57 \text { (95\% CI 52-74) } \\ & \text { disharmonic profile: VIQ 72, PIQ } \\ & 55 . \\ & \text { WPPSI-III-NL 2.6-7.11 years) TIQ } 59 \\ & (95 \% \text { CI 54-71), VIQ } 72 \text { (68-85), } \\ & \text { PIQ 63 (57-77) } \\ & \text { Mild intellectual delay } \\ & \text { Triangular-shaped face with } \\ \text { Head } & \text { pointed chin } \\ & \text { Normal blond straight head hair, } \\ \text { Hair } & \text { hypertrichosis of arms and back } \\ & \text { Epicanthus, upslanted palpebral } \\ \text { Eyes } & \text { fissures } \\ & \text { Hyperopia +6.5 D }\end{array}$

Nose $\quad$ Full nasal tip, prominent columella

Philtrum Deeply grooved
Not applicable

Coarse face, slight frontal bossing

Hypertrichosis with lanugo hair on face

Slight right epicanthus, wide-set eyes, remarkable broad left eyebrow with long hairs

Long, smooth philtrum

Prominent columella

WISCIII at 8 years

Total IQ 58, verbal IQ 62, perfomal IQ 69 Attends school problems

Slight frontal bossing, triangularshaped face with pointed chin

Curly hair

Wide-set, slight epicanthus, downslanting palpebral fissures

Smooth

Normal for children with severe learning
Feeding problems during neonatal period with tube feedings. Persistent FTT

$93.47 \mathrm{~cm}(-5.11 \mathrm{SD})$ at 6 years of age

$11.79 \mathrm{~kg}$ (0\%ile, z-score -5.71) at 6 years of age

$41 \mathrm{~cm}(-8.7 \mathrm{SD})$ at 6 years

Rolled over at 3 months. Crawled at 18 months. Walked independently at 4 years. Approximately 20 words

No formal developmental assessment. Attends elementary school receiving special education through the public school system. Uses communication devices for expressive language. Receptive language seems good

Oval-shaped face with mild bitemporal constriction

Fine hair

Mild telecanthus, upslanting, short and narrow palpebral fissures hyperopia, mild bilateral optic nerve hypoplasia

Prominent nose with low-hanging prominent columella

Smooth 
Table 1 Clinical features of four patients with de novo mutations in the last exon of the ZNF148 gene (Continued)

\begin{tabular}{|c|c|c|c|c|}
\hline Mouth & Full lower lip & Normal & $\begin{array}{l}\text { Wide-set points of upper } \\
\text { vermilion }\end{array}$ & $\begin{array}{l}\text { Wide mouth with thin upper } \\
\text { vermillion border; highly arched } \\
\text { palate, widely spaced teeth of } \\
\text { abnormal shape }\end{array}$ \\
\hline Ears & Prominent crus helicis of right ear & Large & Low-set and posteriorly rotated & $\begin{array}{l}\text { Unusual shape with underfolded } \\
\text { helix and prominent anthelix }\end{array}$ \\
\hline Jaw & Pointed chin & $\begin{array}{l}\text { Slight micrognathia, } \\
\text { pointed chin }\end{array}$ & Pointed chin & Pointed chin with prognathia \\
\hline Thorax & Normal & $\begin{array}{l}\text { Wide-spaced inverted } \\
\text { nipples }\end{array}$ & Normal & Normal \\
\hline Limbs & $\begin{array}{l}\text { Congenital trigger thumb, } \\
\text { dysplastic nail of left hallux }\end{array}$ & $\begin{array}{l}\text { Bilateral talipes } \\
\text { equinovarus with } \\
\text { deeply grooved foot } \\
\text { soles }\end{array}$ & Pedes plani, slight genua valga & Bilateral talipes equinovarus \\
\hline Genital & Normal & $\begin{array}{l}\text { Undescended right } \\
\text { testis }\end{array}$ & Normal & Normal \\
\hline Puberty & No & No & $\begin{array}{l}\text { Early breast development } \\
\text { starting at } 8 \text { years }\end{array}$ & No \\
\hline Epilepsy & No & $\begin{array}{l}+ \text { (EEG burst } \\
\text { suppression) }\end{array}$ & No & No \\
\hline Brain & $\begin{array}{l}\text { MRI brain: thin corpus callosum, } \\
\text { slightly delayed myelination, } \\
\text { suggestion of bilateral parieto- } \\
\text { occiptalpolymicrogyria, periven- } \\
\text { tricular hyperintensities }\end{array}$ & $\begin{array}{l}\text { MRI brain: absent } \\
\text { corpus callosum, wide } \\
\text { lateral ventricles, } \\
\text { bleeding }\end{array}$ & $\begin{array}{l}\text { MRI brain: absent corpus } \\
\text { callosum, colpocephaly }\end{array}$ & $\begin{array}{l}\text { CT brain: suspected partial } \\
\text { deficiency of the rostrum of the } \\
\text { corpus callosum; non-specific foci } \\
\text { in the left frontal and left occipital } \\
\text { skull of unknown etiology. No MRI }\end{array}$ \\
\hline Heart & Normal & $\begin{array}{l}\text { Open ductus arteriosus, } \\
\text { heavy heart - no } \\
\text { evidence of } \\
\text { cardiomyopathy }\end{array}$ & Normal & $\begin{array}{l}\text { Coarctation of aorta, mitral valve } \\
\text { stenosis }\end{array}$ \\
\hline Kidneys & Renal ultrasound not done yet & $\begin{array}{l}\text { Multicystic dysplastic } \\
\text { left kidney, pyelectasia/ } \\
\text { hydronephrosis of right } \\
\text { kidney }\end{array}$ & Normal renal ultrasound & $\begin{array}{l}\text { Multicystic dysplastic right kidney. } \\
\text { History of multiple urinary tract } \\
\text { infections. Normal voiding } \\
\text { cystourethrogram }\end{array}$ \\
\hline Endocrine & Not investigated & Not investigated & $\begin{array}{l}\text { Early signs of puberty, growth } \\
\text { hormone deficiency }\end{array}$ & $\begin{array}{l}\text { Normal bone age and growth } \\
\text { hormone status }\end{array}$ \\
\hline Other & $\begin{array}{l}\text { Recurrent upper airway infections, } \\
\text { delayed intestinal mobility } \\
\text { problems, late first tooth } \\
\text { eruption }>3 \text { years }\end{array}$ & Short neck & Frequent rhinitis in the first year & $\begin{array}{l}\text { Frequent otitis media status post } \\
\text { tympanostomy and tube } \\
\text { placement }\end{array}$ \\
\hline
\end{tabular}

corpus callosum but based on the patients' phenotypes this is highly expectable. Homozygous ZNF148 knock-out mice are not viable while heterozygous mice show no consistency in observed phenotype [16]. Besides its four ZNF motifs, the protein contains an N-terminal acidic domain, three basic domains, a serine-rich/proline, glutamic acid, serine, threonine (PEST)-rich domain, and a C-terminal activation domain (Fig. 2 and [12]).

Over 30 target genes of ZNF148 have been identified to date [16]. A number of these target genes can be hypothetically linked to the clinical phenotype observed in the patients. For example, ZNF148 directly activates promoter activity of the growth hormone $(\mathrm{GH})$ receptor $[17,18]$ and altered ZNF148 dosage or altered protein function may therefore be related to the short stature observed (Table 1). Likewise, in vitro reporter assays showed that ZNF148 is a key regulator of PKD1 and PKD2 gene promoters. The kidney abnormalities observed in patients 2 and 4 may therefore be related to aberrant ZNF148-driven PKD gene transcription [19]. The phenotype of patient 4 resembles FHS, which has some similarities with Rubinstein-Taybi syndrome (RTS) such as short stature, prominent columella, and renal and cardiac anomalies [20]. While our patients have a prominent columella and some have heart defects, the overall resemblance is still limited. It is notable though that ZNF148 binds the RTS-related EP300 protein, indicating that shared pathways may be affected in our patients and RTS patients. These pathways regulated by EP300-ZNF148 interactions are likely involved in chromatin remodeling by histon deacetylation via complexing with, for example, HDAC1 or HDAC3 [21-23].

All patients harboring ZNF148 mutations had maldevelopment of the corpus callosum (MCC), which can be related to abnormal neuronal proliferation or migration, 

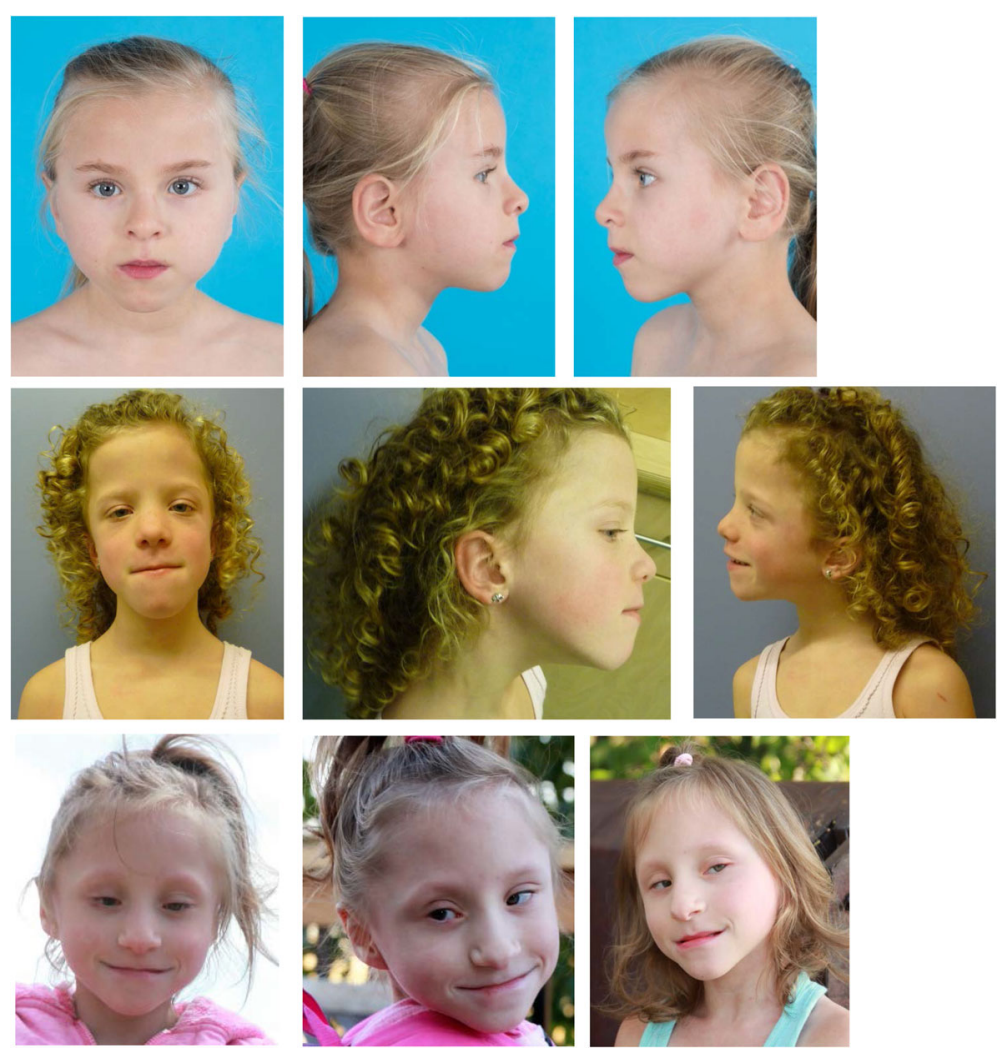

Fig. 1 Photographs of (from top to bottom) patients 1, 3, and 4 with de novo truncating ZNF148 mutations. Note common features like triangular-shaped face with pointed chin and wide-set eyes

abnormal telencephalic midline patterning, or abnormal axonal growth or guidance (reviewed in [24]). Although over 50 genes have currently been linked to MCC [24], none of these has clear overlap with ZNF148 with regard to biological function or the cellular pathways they are involved in. In addition, the clinical phenotype of our patients is different from known syndromes in which MCC is a feature [24]. We thus postulate ZNF148 as novel genetic factor required for corpus callosum development.

As all four de novo PTC mutations occurred in the last exon of the ZNF148 gene, they most probably do not to lead to nonsense-mediated RNA decay (NMD), but rather are likely to yield a truncated protein [25]. This pattern of "last exon de novo PTC mutations" is also observed for several other genes, where pathogenic PTCs only appear to be located in the last exon (occasionally with rare exceptions in the penultimate exon) or where last exon mutations give a distinct clinical phenotype, e.g. SOX10, EZH2, NOTCH3, KAT6A, and ASXL1 [26-30]. Although all four mutations in ZNF148 are distal to its $\mathrm{C} 2 \mathrm{H} 2$ zinc finger domains, they truncate the protein in such a way that it is missing the larger part of the C-terminal activation domain (Fig. 2). These truncated proteins would be expected to have altered biological function, e.g. inability to interact with components of transcription-initiator or transcription-repressor complexes (LoF), to have a dominant negative effect or to have a "gain-of-function (GoF)" effect. The ExAC database currently lists two variants that may lead to NMD, both of which are located at the canonical splice acceptor site of intron 5. Still, it is difficult to draw conclusions on whether NMD of ZNF148 transcript is "benign," because of: (1) the small number of individuals in ExAc (i.e. only two LoF mutations per 110,000 alleles); (2) the lack of phenotypic data for these two individuals and the fact that corpus callosum abnormalities may have subtle clinical manifestation; and (3) the fact the splice effect of these two variants has only been predicted by in silico tools. No deletions or other genetic aberrations of ZNF148 have thus far been reported in literature, while the DECIPHER database [31] does currently not report single gene copy number variants for ZNF148. It remains therefore elusive whether HI of the ZNF148 gene can lead to a clinical phenotype and whether that phenotype would be similar to that associated with protein truncation, the likely mechanism in our patients. Thus, a rationale exists for further studies that investigate by which molecular mechanisms and molecular interactions the ZNF148 protein is involved in the genesis of clinical phenotypes, in particular corpus callosum abnormalities. 


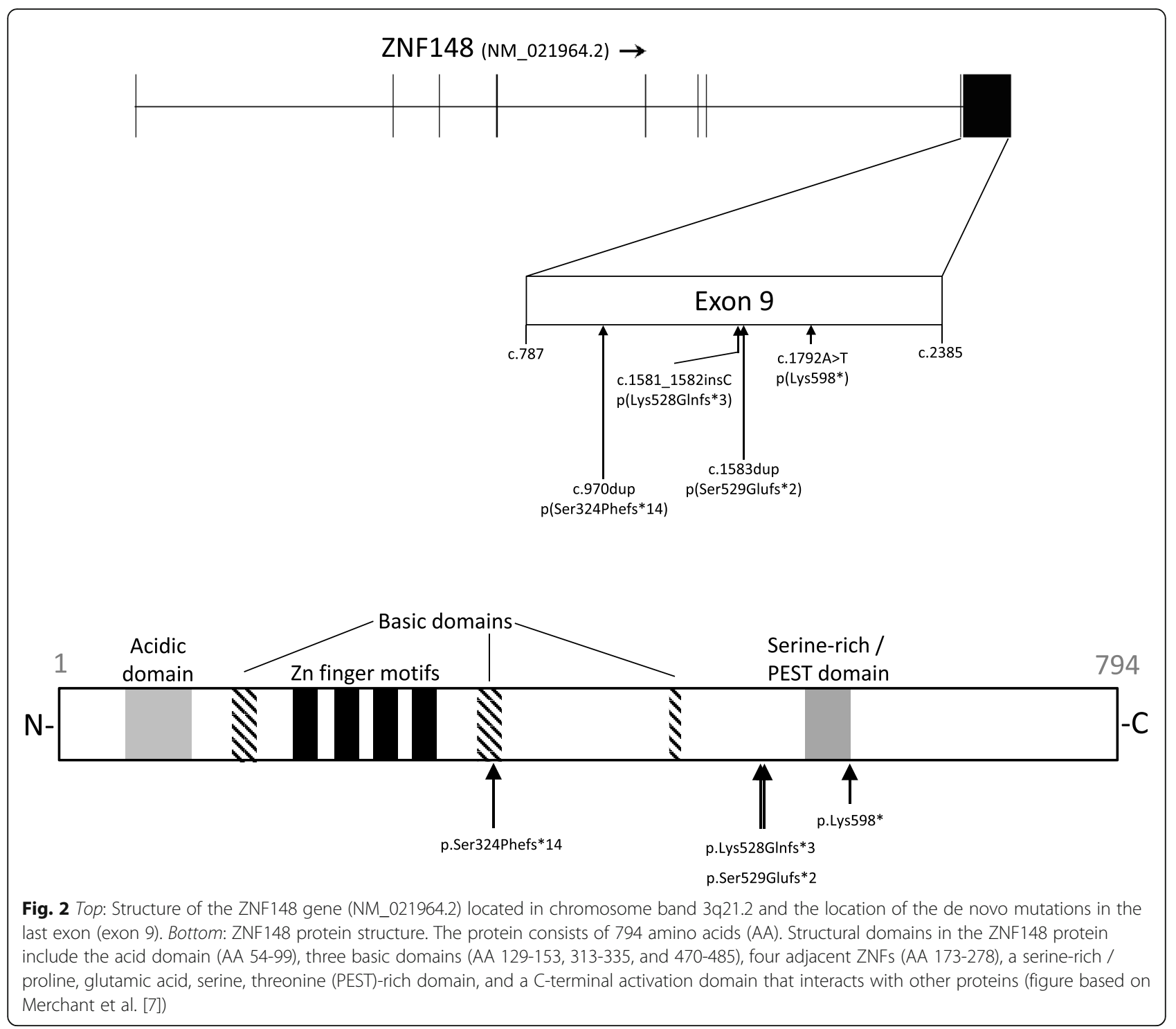

\section{Conclusion}

Based on the de novo ZNF148 gene mutation rate in our patients, the nature of these mutations (i.e. de novo and truncating), the location of the observed mutations in the last exon, and the patients' overlapping clinical phenotypes, we provide evidence that de novo truncating ZNF148 mutations cause a syndrome characterized by ID, short stature, aberrant head size (from microcephaly to mild macrocephaly), feeding problems, variable facial characteristics including telecanthus/wide nasal bridge, low columella and pointed chin, cardiac and renal malformations, and talipes. We furthermore postulate that the ZNF148 protein is a hitherto unrecognized but crucial transcription factor in the development of the corpus callosum. Our study illustrates the advantage of WES in a large cohort using a parent-offspring trio approach for identifying novel genes involved in rare human diseases, based on recurrence of mutations and clinical and statistical evidence.

Acknowledgements

Not applicable.

\section{Funding}

The study was funded by the authors' respective academic departments mentioned on the title page.

\section{Availability of data and materials}

Not applicable: all relevant genetic data are given in manuscript. The complete WES datasets obtained from routine diagnostic genetic testing are not made publicly available. Permission from patients/parents was only sought for sharing of clinical data, clinical photographs, and relevant mutations identified, while no explicit permission was asked for sharing of the patients' complete WES dataset.

\section{Authors' contributions}

SJCS and AJE designed the study and wrote the draft manuscript; AJE, CMAR, AFE, JF, and HGB did the clinical workup and collected patient data; SHL and CG did the statistical analyses; SJCS, RP, WMN, HGY, KR, and APA 
analyzed the exome data and authorized the initial diagnostic laboratory reports; all authors contributed to the final version of the paper. All authors read and approved the final manuscript.

\section{Competing interest}

The authors declare that they have no competing interests.

\section{Consent for publication}

Written informed consent was obtained for the diagnostic procedure. Subsequently explicit written consent was sought for inclusion of patients' photographs and clinical data in this manuscript. The consent was given on behalf of patients by their parent(s) as patients were underage.

\section{Ethics approval and consent to participate}

Written informed consent of the patients' parents was obtained before inclusion in the exome sequencing study/diagnostic exome sequencing. This study was approved by the local institutes under the realm of routine diagnostic genetic testing. Patients' parents were counseled by a clinical geneticist and gave written informed consent for the diagnostic procedure. This study conformed to the principles of the Declaration of Helsinki. This study took place in the Netherlands where WES, usually performed on trio-samples, is standard care in the genetic diagnostic workup of patients with developmental delay, ID, and/or congenital malformations. This was the case for patients $1-3$, where such genetic diagnostic testing led to the identification of the de novo ZNF148 variants. As a result, these patients or their families were not subjected to additional investigations for the purposes of research according to Dutch law (i.e. the Medical Research Involving Human Subjects Act of February 26th 1998, known in Dutch as "Wet Mensgebonden Onderzoek (WMO)"; law BWBR0009408). Because patients are not subject to additional procedures and are not required to follow rules of behavior, no formal ethical board review is required for this retrospective research/patient file research type of study, where data are already available from routine diagnostic testing (see website of the Competent Authority for medical research in the Netherlands, the "Central Committee on Research Involving Human Subjects" at www.ccmo.nl/en/ non-wmo-research and www.ccmo.nl/en/your-research-does-it-fall-under-thewmo). Patient 4 received standard medical care by an American Board of Medical Genetics (ABMG)-certified clinical geneticist at Shodair Children's Hospital in Helena, Montana, USA (ABMG certificate number for Abdallah Elias, MD: 2013048). The Shodair Genetics Laboratory is a clinical laboratory certified by the Centers for Medicare and Medicaid Services (CMS) through Clinical Laboratory Improvement Amendments (CLIA; certificate number: 27D0652530). CLIA regulations include federal standards applicable to all U.S. facilities or sites that test human specimens for health assessment or to diagnose, prevent, or treat disease (wwwn.cdc.gov/ clia/). Shodair Hospital is also accredited by the Joint Commission (HCO ID 1964), recognized nationwide as a symbol of quality that reflects an organization's commitment to meeting certain performance standards (www.jointcommission.org/). The ZNF184 variant was identified in patient 4 through routine diagnostic clinical genetic testing. Thus, the work reported for patient 4 is the result of routine provision of medical attention at the standard of care, with data collected solely for patient care purposes. No additional data were collected or medical intervention undertaken for the purposes of this study. As such, a Research Involving Human Subjects Committee was not convened.

\section{Author details}

'Department of Clinical Genetics, Maastricht University Medical Center (MUMC+), PO Box 58006202, AZ, Maastricht, The Netherlands. ${ }^{2}$ Department of Genetics, University of Groningen, University Medical Center Groningen (UMCG), Groningen, The Netherlands. ${ }^{3}$ Department of Medical Genetics, Shodair Children's Hospital, Helena, MT, USA. ${ }^{4}$ Department of Genetics, Radboud University Medical Center (RUMC), Nijmegen, The Netherlands.

Received: 19 July 2016 Accepted: 1 December 2016 Published online: 13 December 2016

\section{References}

1. Huntley S, Baggott DM, Hamilton AT, Tran-Gyamfi M, Yang S, Kim J, et al. A comprehensive catalog of human KRAB-associated zinc finger genes: insights into the evolutionary history of a large family of transcriptional repressors. Genome Res. 2006;16(5):669-77.
2. Nagai $R$, Friedman $S L$, Kasuga M. The biology of Krüppel-like factors. Tokyo: Springer; 2009.

3. Veltman JA, Brunner HG. De novo mutations in human genetic disease. Nat Rev Genet. 2012;13(8):565-75.

4. de Ligt J, Willemsen MH, van Bon BW, Kleefstra T, Yntema HG, Kroes T, et al. Diagnostic exome sequencing in persons with severe intellectual disability. N Engl J Med. 2012;367(20):1921-9.

5. Samocha KE, Robinson EB, Sanders SJ, Stevens C, Sabo A, McGrath LM, et al. A framework for the interpretation of de novo mutation in human disease. Nat Genet. 2014;46(9):944-50.

6. Lelieveld SH, Reijnders MR, Pfundt R, Yntema HG, Kamsteeg EJ, de Vries P, et al. Meta-analysis of 2,104 trios provides support for 10 new genes for intellectual disability. Nat Neurosci. 2016;19(9):1194-6.

7. Sobreira N, Schiettecatte F, Valle D, Hamosh A. GeneMatcher: a matching tool for connecting investigators with an interest in the same gene. Hum Mutat. 2015;36(10):928-30

8. Exome Aggregation Consortium, Lek M, Karczewski K, Minikel E, Samocha K, Banks $E$, et al. Analysis of protein-coding genetic variation in 60,706 humans. http://biorxiv.org/content/early/2015/10/30/030338. Accessed 19 May 2016.

9. ClinVar submission of variant RCV000181114.1. https://www.ncbi.nlm.nih. gov/clinvar/RCV000181114.1. Accessed 17 Sept 2016.

10. Exome Variant Server. www.evs.gs.washington.edu/EVS. Accessed 10 May 2016

11. Huang N, Lee I, Marcotte EM, Hurles ME. Characterising and predicting haploinsufficiency in the human genome. PLoS Genet. 2010;6(10):e1001154.

12. Merchant JL, Bai L, Okada M. ZBP-89 mediates butyrate regulation of gene expression. J Nutr. 2003;133(7 Suppl):2456S-60S.

13. Protein BLAST: search protein databases using a protein query. blast.ncbi. nlm.nih.gov/Blast.cgi?PAGE = Proteins. Accessed 20 May 2016.

14. Brianspan Developmental Transcriptome. Atlas of the developing human brain, data for ZNF148. www.brainspan.org/rnaseq/searches?exact_match= false\&search_term=ZNF148\&search_type=gene. Accessed 10 Sept 2016.

15. Miller JA, Ding SL, Sunkin SM, Smith KA, Ng L, Szafer A, et al. Transcriptional landscape of the prenatal human brain. Nature. 2014;508(7495):199-206.

16. Hahn S, Hermeking H. ZNF281/ZBP-99: a new player in epithelial-mesenchymal transition, stemness, and cancer. J Mol Med (Berl). 2014;92(6):571-81.

17. $\mathrm{Xu} Q \mathrm{Q}$, Springer $\mathrm{L}$, Merchant J, Jiang $\mathrm{H}$. Identification of zinc finger binding protein 89 (ZBP-89) as a transcriptional activator for a major bovine growth hormone receptor promoter. Mol Cell Endocrinol. 2006;251:88-95.

18. Thimmarayappa J, Sun J, Schultz LE, Dejkhamron P, Lu C, Giallongo A, et al. Inhibition of growth hormone receptor gene expression by saturated fatty acids: role of Kruppel-like zinc finger factor, ZBP-89. Mol Endocrinol. 2006; 20(11):2747-60.

19. Lantinga-van Leeuwen IS, Leonhard WN, Dauwerse H, Baelde HJ, van Oost BA, Breuning $\mathrm{MH}$, et al. Common regulatory elements in the polycystic kidney disease 1 and 2 promoter regions. Eur J Hum Genet. 2005;13(5):649-59.

20. Nowaczyk MJM, Nikkel SM, White SM. Floating-Harbor Syndrome. In: Pagon RA, Adam MP, Ardinger HH, Wallace SE, Amemiya A, Bean $\sqcup H$, et al., editors. GeneReviews ${ }^{\ominus}$ [Internet]. Seattle, WA: University of Washington, Seattle; 1993-2016.

21. Bai L, Merchant JL. Transcription factor ZBP-89 cooperates with histone acetyltransferase p300 during butyrate activation of p21waf1 transcription in human cells. J Biol Chem. 2000;275(39):30725-33.

22. Ye CG, Liu L, Chen GG, Tang XL, He Z, He ML, et al. ZBP-89 reduces histone deacetylase 3 by degrading IkappaB in the presence of Pin1. J Transl Med. 2015;13:23.

23. Wu Y, Zhang $X$, Salmon M, Zehner ZE. The zinc finger repressor, ZBP-89, recruits histone deacetylase 1 to repress vimentin gene expression. Genes Cells. 2007;12(8):905-18.

24. Edwards TJ, Sherr EH, Barkovich AJ, Richards LJ. Clinical, genetic and imaging findings identify new causes for corpus callosum development syndromes. Brain. 2014;137:1579-613.

25. Kuzmiak HA, Maquat LE. Applying nonsense-mediated mRNA decay research to the clinic: progress and challenges. Trends Mol Med. 2006;12:306-16.

26. Inoue K, Khajavi M, Ohyama T, Hirabayashi S, Wilson J, Reggin JD, et al. Molecular mechanism for distinct neurological phenotypes conveyed by allelic truncating mutations. Nat Genet. 2004;36(4):361-9.

27. Tatton-Brown K, Murray A, Hanks S, Douglas J, Armstrong R, Banka S, et al Weaver syndrome and EZH2 mutations: Clarifying the clinical phenotype. Am J Med Genet A. 2013:161A(12):2972-80.

28. Tham E, Lindstrand A, Santani A, Malmgren $H$, Nesbitt A, Dubbs HA, et al. Dominant mutations in KAT6A cause intellectual disability with recognizable syndromic features. Am J Hum Genet. 2015;96(3):507-13. 
29. Gripp KW, Robbins KM, Sobreira NL, Witmer PD, Bird LM, Avela K, et al. Truncating mutations in the last exon of $\mathrm{NOTCH} 3$ cause lateral meningocele syndrome. Am J Med Genet A. 2015;167A(2):271-81.

30. Hoischen A, van Bon BW, Rodríguez-Santiago B, Gilissen C, Vissers LE, de $\checkmark$ ries $P$, et al. De novo nonsense mutations in ASXL1 cause Bohring-Opitz syndrome. Nat Genet. 2011:43(8):729-31.

31. The Database of Chromosomal Imbalance and Phenotype in Humans using Ensembl Resources (Decipher), data on the ZNF148 gene. https:/decipher. sanger.ac.uk/search?q=ZNF148\#consented-patients/results. Accessed 8 Sept 2016.

Submit your next manuscript to BioMed Central and we will help you at every step:

- We accept pre-submission inquiries

- Our selector tool helps you to find the most relevant journal

- We provide round the clock customer support

- Convenient online submission

- Thorough peer review

- Inclusion in PubMed and all major indexing services

- Maximum visibility for your research

Submit your manuscript at www.biomedcentral.com/submit
Biomed Central 